\title{
In vitro antioxidant activity of stem bark of Trichilia catigua Adr. Juss
}

\author{
JEAN PAUL KAMDEM ${ }^{1,5 *}$ \\ SÍLVIO TERRA STEFANELLO ${ }^{1}$ \\ ALINE AUGUSTI BOLIGON ${ }^{2}$ \\ CAROLINE WAGNER ${ }^{3}$ \\ IGE JOSEPH KADE ${ }^{4}$ \\ ROMAIANA PICADA PEREIRA ${ }^{1}$ \\ ALESSANDRO DE SOUZA PRESTE ${ }^{1}$ \\ DANIEL HENRIQUE ROOS ${ }^{1}$ \\ EMILY PANSERA WACZUK ${ }^{1}$ \\ ANDRE STORTI APPEL ${ }^{1}$ \\ MARGARETH LINDE ATHAYDE ${ }^{2}$ \\ DIOGO ONOFRE SOUZA ${ }^{5}$ \\ JOÃO BATISTA TEIXEIRA ROCHA ${ }^{1 *}$ \\ 1 Departamento de Química, Programa \\ de Pós-Graduação em Bioquímica \\ Toxicológica, Universidade Federal \\ de Santa Maria, Santa Maria \\ RS 97105-900, Brazil
}

2 Departamento de Farmácia Industrial Programa de Pós-Graduação em Ciências Farmacêuticas, Universidade Federal de Santa Maria, Santa Maria RS 97105-900, Brazil

3 Universidade Federal do Pampa Campus Caçapava do Sul, Caçapava do Sul, RS CEP 96570-000, Brazil

${ }^{4}$ Department of Biochemistry, Federal University of Technology, PMB 704 Akure, Ondo State, Nigeria

5 Departamento de Bioquímica Instituto de Ciências Básicas da Saúde Universidade Federal do Rio Grande do Sul Porto Alegre, RS, Brazil

\begin{abstract}
Antioxidant activity of the ethanolic extract and fractions from the stem bark of $T$. catigua was investigated. $I C_{50}$ (for DPPH scavenging) by T. catigua varied from $9.17 \pm$ 0.63 to $76.42 \pm 5.87 \mu \mathrm{g} \mathrm{mL}^{-1}$ and total phenolic content varied from $345.63 \pm 41.08$ to $601.27 \pm 42.59 \mu \mathrm{g} \mathrm{GAE} \mathrm{g}^{-1}$ of dry extract. $\mathrm{Fe}^{2+}$-induced lipid peroxidation was significantly reduced by the ethanolic extract and fractions. Mitochondrial $\mathrm{Ca}^{2+}$-induced dichlorofluorescein oxidation was significantly reduced by the ethanolic extract in a concentration-dependent manner. Ethanolic extract reduced mitochondrial $\Delta \psi_{\mathrm{m}}$ only at high concentrations (40-100 $\mu \mathrm{g} \mathrm{mL}^{-1}$ ), which indicates that its toxicity does not overlap with its antioxidant effects. Results suggest involvement of antioxidant activities of T. catigua in its pharmacological properties.
\end{abstract}

Keywords: Trichilia catigua (Meliaceae), antioxidant, flavonoids, phenolics, reactive oxygen species, oxidative stress

Accepted June 11, 2012

*Correspondence; e-mail: jbtrocha@yahoo.com.br; kamdemjeanpaul2005@yahoo.fr 
Many plants contain substantial amounts of antioxidants such as vitamins $\mathrm{C}$ and $\mathrm{E}$, carotenoids, flavonoids and tannins that can scavenge free radicals from the human body (1). Since ancient times, a high percentage of the populations of many developed countries have been using medicinal plants in the treatment of different pathologies, including neurodegenerative diseases in which free radical assaults are implicated in their etiology.

Trichilia catigua, is a plant used in Brazil as an aphrodisiac and neurostimulant. It exhibits a variety of pharmacological properties, including antidepressive and anti-inflammatory ones, and its use has been reported to be safe with no known side effects or toxicity in healthy human volunteers (2). Phytochemical reports on T. catigua indicated that the plant contains omega-phenyl alkanes, omega-phenyl alkanoic acids, omega-phenyl-gamma-lactones, alkyl-gamma-lactones, alkenyl-gamma-lactones, fatty acids, $\beta$-sitosterol, stigmasterol, campesterol, epicatechin, cinchonains (Ia, Ib, IIa, IIb), catiguanins A and $\mathrm{B}$, procyanidins $\mathrm{B} 2$ and $\mathrm{C} 1$, tannins and a mixture of flavalignans $(3,4)$.

It is of particular pharmacological significance that many pathological processes in which T. catigua exerts its beneficial action can be associated with overproduction of reactive oxygen species (ROS) which can impair energy metabolism via oxidative changes in key mitochondrial components (5).

Considering the fact that $T$. catigua has been widely employed empirically in folkloric medicine in the management of free radical related diseases, and that there is little information in the literature about the potential antioxidant properties of $T$. catigua, we investigated whether the ethanolic extract and fractions of different polarities extracted from the stem bark of T. catigua exhibited in vitro antioxidant activity using chemical and biological models.

\section{EXPERIMENTAL}

\section{Chemicals}

All chemicals used, including solvents, were of analytical grade. 1,1-Diphenyl-2-picryl hydrazyl (DPPH), Folin Ciocalteu's phenol reagent, malonaldehyde bis-(dimethyl acetal) (MDA), thiobarbituric acid, sodium dodecyl sulfate, ascorbic acid, 2',7'-dichlorofluorescein diacetate (DCFH-DA), Tris- $\mathrm{HCl}$, ethylene glycol tetraacetic acid (EGTA), quercetin, rutin, chlorogenic acid and gallic acid were purchased from Sigma Chemical Co. (USA). 4-(2-Hydroxyethyl)-1-piperazine ethanesulfonic acid (HEPES), ferrous sulfate, mannitol and sucrose were obtained from Vetec (Brazil).

\section{Plant collection and separation of the different fractions}

Extract of Trichilia catigua bark was obtained from Ely Martins (Ribeirão Preto, São Paulo, Brazil), in 2007, registered under the number CAT-i0922 (Farm. Resp.: Ely Ap. Ramos Martins). The stem bark powder of T. catigua (100 g) was macerated at room temperature with $70 \%$ ethanol and extracted for a week. On the seventh day, the combined ethanolic extract was filtered and the solvent was fully evaporated under reduced pres- 
sure to give a brown solid (11.61 g). This was divided into two parts and one part was suspended in water and partitioned successively with dichloromethane, ethyl acetate and $n$-butanol $(3 \times 50 \mathrm{~mL}$ for each solvent). Dichloromethane was added to one part of the extract $(1: 1, V / V)$ and the mixture was allowed to remain at room temperature for 15 min. The solution was decanted and the solvent was evaporated to obtain the dichloromethane fraction $\left(\mathrm{CH}_{2} \mathrm{Cl}_{2}, 1.98 \mathrm{~g}\right)$. The other fractions (ethyl acetate, AcOEt) and butanolic fraction $(n-\mathrm{BuOH})$ were processed as described for the dichloromethane fraction and the quantities obtained after evaporation were $1.05 \mathrm{~g}$ and $1.52 \mathrm{~g}$, respectively.

In this procedure, the extract was suspended 3 times with each solvent $(3 \times 50 \mathrm{~mL})$. The fractions and $\mathrm{EtOH}$ extract were then diluted in ethanol in order to prepare different concentrations $\left(10,40,100\right.$ and $\left.400 \mu \mathrm{g} \mathrm{mL}^{-1}\right)$. T. catigua is normally used as a tea; consequently, hot and cold water extracts from T. catigua were tested to compare their antioxidant capacities with the ethanolic extract and fractions.

\section{Animals}

Male Wistar rats, weighing 270-320 g and aged from 2.5 to 3.5 months, from our own breeding colony (Animal House-holding, UFSM, Brazil) were kept in cages with free access to food and water in a room with controlled temperature $\left(22 \pm 3{ }^{\circ} \mathrm{C}\right)$ and in $12 \mathrm{~h}$ light/dark cycle. The protocol of this study has been approved by the Brazilian Association for Laboratory animal Science (COBEA).

\section{Antioxidant assays}

The free radical scavenging activity of the T. catigua extract was measured with the stable radical 1,1-diphenyl-2-picryl hydrazyl (DPPH) in terms of hydrogen-donating or radicals scavenging activity. A solution of DPPH $\left(0.3 \mathrm{mmol} \mathrm{L}^{-1}\right)$ in ethanol was prepared, and $100 \mu \mathrm{L}$ of this solution was added to $20 \mu \mathrm{L}$ of each fraction and ethanolic extract at different concentrations $(10,40,100$ and $400 \mu \mathrm{g} \mathrm{mL}-1$ ). Ethanol and ascorbic acid, at the same concentrations used for fractions and ethanolic extract, were used as negative and positive controls, respectively. After 30 minutes, absorbances were measured at $518 \mathrm{~nm}$ in an ELISA plate reader (TP-Reader, Brazil).

\section{Analysis of phenolics}

For the determination of total phenolic content, samples of the extract/fraction (10-400 $\mu \mathrm{g} \mathrm{mL}^{-1}$ ) were added to a test tube and the volume was adjusted to $1.4 \mathrm{~mL}$ with distilled water. Then, $0.2 \mathrm{~mL}$ of $10 \%$ Folin-Ciocalteu reagent (diluted $1: 1$ with water) and $0.4 \mathrm{~mL}$ of sodium carbonate solution $(7.5 \%)$ were added sequentially to the test tube. The tubes were then incubated for $40 \mathrm{~min}$ at $45^{\circ} \mathrm{C}$ and the absorbance was measured at $725 \mathrm{~nm}$ in a spectrophotometer (SP-2000UV, Biospectro, Brazil). The standard curve was prepared using $0,1,2.5,5,10$ and $15 \mu \mathrm{g} \mathrm{mL}-1$ solutions of gallic acid $\left(0.1 \mathrm{mg} \mathrm{mL}^{-1}\right)$. Total phenol value was calculated and expressed as the microgram gallic acid equivalent $\left(\mu \mathrm{g} \mathrm{GAE}^{-1}\right.$ ) of dry extract. 
In vitro $F e^{2+}$-induced lipid peroxidation in the brain

Rats were decapitated; whole brain was dissected, placed on ice and weighed. Tissues were immediately homogenized in cold $10 \mathrm{mmol} \mathrm{L}^{-1}$ Tris- $\mathrm{HCl}, \mathrm{pH} 7.4$ (1/10, mass/ volume). The homogenate was centrifuged for $10 \mathrm{~min}$ at $3600 \times \mathrm{g}$ to yield a pellet, which was discarded, and a low-speed supernatant (S1) was used for the thiobarbituric acid reactive substances (TBARS) assay.

Aliquots of the brain homogenate and the pro-oxidant agent $\left(10 \mu \mathrm{mol} \mathrm{L} \mathrm{L}^{-1} \mathrm{FeSO}_{4}\right)$ were incubated for $1 \mathrm{~h}$ at $37^{\circ} \mathrm{C}$ in the presence or absence of the T. catigua extract (10-20 $\mu \mathrm{g} \mathrm{mL}^{-1}$ ). To the reaction mixture, $8.5 \%$ sodium dodecyl sulfate (SDS), acetic acid/ $\mathrm{HCl}$ ( $\mathrm{pH} 3.4$ ) and $0.6 \%$ thiobarbituric acid (TBA) were subsequently added and the mixture was incubated at $100{ }^{\circ} \mathrm{C}$ for $1 \mathrm{~h}$. Lipid peroxidation (LPO) was measured by TBARS formation as described by Puntel et al. (6). Color was read at $532 \mathrm{~nm}$ using an ELISA plate reader. Standard curve of malondialdehyde (MDA) was used to quantify TBARS production in brain homogenates.

\section{Quantification of phenolics and flavonoids by HPLC-DAD}

The phenolics and flavonoids in the extract were quantified by reverse phase chromatographic analysis by the method described by Laghari et al. (7), with slight modifications. Reverse phase chromatographic analysis was carried out under gradient conditions using $C_{18}$ column $(4.6 \mathrm{~mm} \times 250 \mathrm{~mm})$ packed with $5-\mu \mathrm{m}$ diameter particles. The mobile phase was water containing $2 \%$ acetic acid (A) and methanol (B), and the composition gradient was: $5 \%$ (B) for $2 \mathrm{~min} ; 25 \%$ (B) until $10 \mathrm{~min} ; 40,50,60,70$ and $80 \%$ (B) every $10 \mathrm{~min}$. All samples and the mobile phase were filtered through a $0.45-\mu \mathrm{m}$ membrane filter (Millipore, USA) and then degassed by ultrasonic bath prior to use. Stock solutions of standards references were prepared in the HPLC mobile phase at a concentration range of $0.031-0.250 \mathrm{mg} \mathrm{mL}^{-1}$ quercetin and rutin, and $0.006-0.250 \mathrm{mg} \mathrm{mL}^{-1}$ for gallic and chlorogenic acids. Quantification was carried out by integration of the peaks using the external standard method, at $257 \mathrm{~nm}$ for gallic acid, $325 \mathrm{~nm}$ for chlorogenic acid and 365 for quercetin and rutin. The flow rate was $0.8 \mathrm{~mL} \mathrm{~min}^{-1}$ and the injection volume was $40 \mu \mathrm{L}$. Chromatographic peaks were confirmed by comparing their retention time and diode-array-UV spectra with those of the reference standards. All chromatography operations were carried out at ambient temperature and in triplicate.

\section{Isolation of rat liver mitochondria}

Rat liver mitochondria were isolated as previously described by Puntel et al. (8), with some modifications. The livers were rapidly removed (within $1 \mathrm{~min}$ ) and immersed in ice-cold "isolation buffer I" containing in mmol L-1: 225 manitol, 75 sucrose, $1 \mathrm{~K}^{+}$-EGTA and $10 \mathrm{~K}^{+}$-HEPES, pH 7.2. The tissue was minced using surgical scissors and then extensively washed. The tissue was then homogenized in a power-driven, tight-fitting Potter-Elvehjem (Reviglass, Brazil) homogenizer with a teflon pestle. The resulting suspension was centrifuged for $7 \mathrm{~min}$ at $2,000 \times g$ in a Hitachi CR 21E centrifuge (Japan). The supernatant was centrifuged again for $10 \mathrm{~min}$ at $12,000 \times \mathrm{g}$. The pellet was resuspended in "isolation buffer II" containing in mmol L-1: 225 manitol, 75 sucrose, $1 \mathrm{~K}^{+}$-EGTA (ethyleneglycol tetraacetic acid) and $10 \mathrm{~K}^{+}$-HEPES [4-(2-hydroxyethyl)-1-piperazine ethane- 
sulfonic acid], $\mathrm{pH} 7.2$, and recentrifuged at $12,000 \times \mathrm{g}$ for $10 \mathrm{~min}$. The supernatant was decanted, and the final pellet was gently washed and resuspended in respiration buffer containing in mmol L-1: 100 sucrose, $65 \mathrm{KCl}, 10 \mathrm{~K}^{+}$-HEPES and $0.05 \mathrm{EGTA}$, pH 7.2, to a protein concentration of $0.6 \mathrm{mg} \mathrm{mL}^{-1}$.

\section{Determination of reactive oxygen species (ROS)}

ROS production in isolated mitochondria was measured using a 2',7'-dichlorofluorescein diacetate (DCFH-DA) fluorescence probe. Mitochondrial suspensions $\left(0.25 \mathrm{mg} \mathrm{mL}^{-1}\right)$ in respiration buffer containing $100 \mathrm{mmol} \mathrm{L}^{-1}$ sucrose, $65 \mathrm{mmol} \mathrm{L}-1 \mathrm{KCl}, 10 \mathrm{mmol} \mathrm{L}^{-1}$ $\mathrm{K}^{+}$-HEPES and $50 \mu \mathrm{mol} \mathrm{L}-1$ EGTA, $\mathrm{pH} 7.2$, were incubated with $10,40,100 \mu \mathrm{g} \mathrm{mL}^{-1}$ of the ethanolic extract $T$. catigua in the presence or absence of $\mathrm{CaCl}_{2}\left(80 \mu \mathrm{mol} \mathrm{L}^{-1}\right)$ (13). Then, $3.33 \mu \mathrm{mol} \mathrm{L}{ }^{-1}$ of DCFH-DA was added to the solution. The formation of the oxidized fluorescent derivative $2^{\prime}, 7^{\prime}$-dichlorofluorescain (DCF) was monitored using a spectrofluorimeter (Shimadzu RF-5301, Japan) with excitation and emission wavelengths of 488 and $525 \mathrm{~nm}$, respectively, and with slit widths of $1.5 \mathrm{~nm}$.

\section{Measurement of mitochondrial membrane potential $\left(\Delta \psi_{m}\right)$}

Mitochondrial membrane potential was estimated by fluorescence changes of safranine $\left(5 \mu \mathrm{mol} \mathrm{L}^{-1}\right)$ recorded by a RF-5301 Shimadzu spectrofluorimeter operating at excitation and emission wavelengths of 495 and $586 \mathrm{~nm}$, respectively, with slit widths of 3 $\mathrm{nm}$. Values of mitochondrial membrane potential $\left(\Delta \psi_{\mathrm{m}}\right)$ were expressed as the percent of control.

\section{Protein estimation}

Protein concentration was measured by the method of Lowry et al. (9), using bovine serum albumin (BSA) as a standard.

\section{Statistical analysis}

Results were expressed as mean \pm SEM (standard error of mean). One-way or two-way ANOVA followed by Duncan's multiple range tests were utilized to evaluate the differences between the groups when appropriate. The data of cold and hot water extracts were compared using $t$-test. Pearson's correlation coefficient was calculated to determine the relationship between two variables.

\section{RESULTS AND DISCUSSION}

Various extracts from the stem barks of T. catigua scavenged DPPH radical in a concentration-dependent manner (Fig. 1a,b), which can be mediated by the different polyphenolic components found in these extracts. The total phenolic content of different crude extracts from T. catigua is given in Table I. The concentration varied from $345.63 \mu \mathrm{g}$ $\mathrm{GAE} \mathrm{g}^{-1}$ (in butanolic fraction) to $601.27 \mu \mathrm{g} \mathrm{GAE} \mathrm{g}^{-1}$ (in ethyl acetate fraction) of plant 

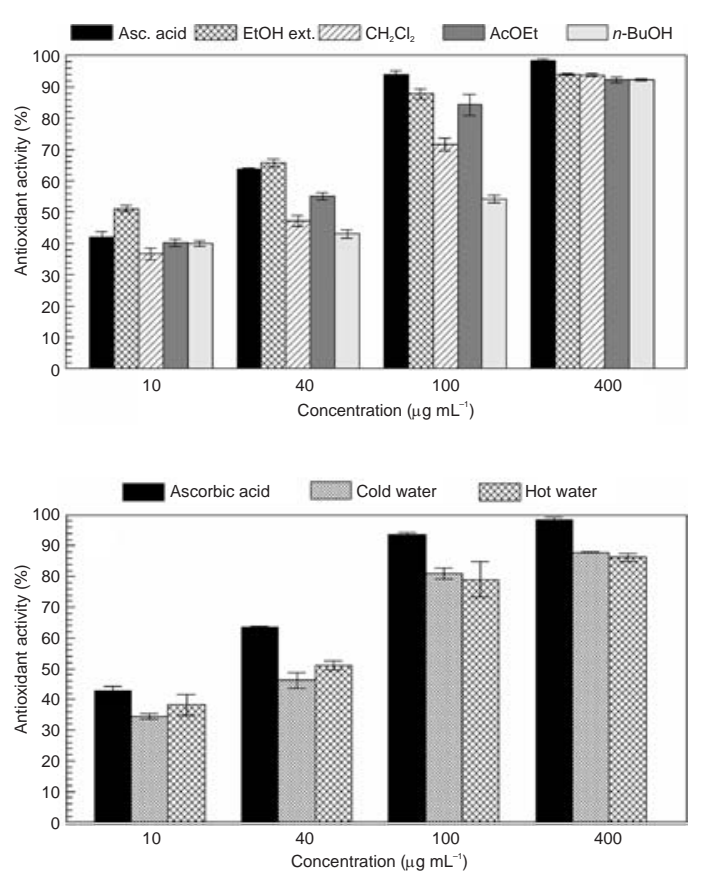

Fig. 1. Quenching of DPPH color by extracts from the stem barks of T. catigua vs. asorbic acid: a) ethanolic, ethyl acetate, dichloromethane and butanolic, b) aqueous (cold and hot water extracts). Mean \pm SEM, $n=3-4$ independent experiments.

extract. Surprisingly, we observed that the highest content of total phenol in ethyl acetate fraction did not correlate with the highest antioxidant activity evaluated by the $\mathrm{DPPH}$ assay. The effectiveness order of $I C_{50}$ (the extract concentration required to inhibit $50 \%$ of DPPH radical) for decolorizing DPPH was: EtOH extract $\left(9.17 \mu \mathrm{g} \mathrm{mL}^{-1}\right)>\mathrm{AcOEt}$ $\left(30.28 \mu \mathrm{g} \mathrm{mL}^{-1}\right)>\mathrm{CH}_{2} \mathrm{Cl}_{2}\left(42.42 \mu \mathrm{g} \mathrm{mL}^{-1}\right)>n-\mathrm{BuOH}\left(76.35 \mu \mathrm{g} \mathrm{mL} \mathrm{m}^{-1}\right)$ (Table I).

Table I. Phenolics and flavonoids from different fractions of $\mathrm{T}$. catigua stem barks and their $\mathrm{IC}_{50}$ values (DPPH)

\begin{tabular}{lccccc}
\hline & $\begin{array}{c}\text { Reference } \\
\text { (ascorbic acid) }\end{array}$ & EtOH extract & $\mathrm{CH}_{2} \mathrm{Cl}_{2}$ & AcOEt & $n$-BuOH \\
\hline $\begin{array}{l}\text { Total phenolics } \\
\left(\mu \mathrm{g} \mathrm{GAE} \mathrm{g}^{-1}\right)\end{array}$ & - & $443.87 \pm 22.23$ & $594.03 \pm 31.32$ & $601.27 \pm 42.59$ & $345.63 \pm 41.08$ \\
Gallic acid $\left(\mathrm{mg} \mathrm{g}^{-1}\right)$ & - & $16.04 \pm 1.68$ & $1.90 \pm 0.19$ & $25.40 \pm 0.30$ & $0.90 \pm 0.10$ \\
$\begin{array}{l}\text { Chlorogenic acid } \\
\left(\mathrm{mg} \mathrm{g}^{-1}\right)\end{array}$ & - & $27.30 \pm 0.20$ & $5.10 \pm 0.30$ & $14.90 \pm 0.40$ & $1.70 \pm 0.30$ \\
Rutin $\left(\mathrm{mg} \mathrm{g}^{-1}\right)$ & - & $7.90 \pm 0.20$ & - & $10.50 \pm 0.20$ & $2.80 \pm 0.10$ \\
Quercetin $\left(\mathrm{mg} \mathrm{g}^{-1}\right)$ & - & $14.2 \pm 0.10$ & $1.10 \pm 0.20$ & $23.70 \pm 0.50$ & $0.70 \pm 0.40$ \\
$I_{50}\left(\mu \mathrm{g} \mathrm{mL}^{-1}\right)$ & $20.72 \pm 1.30^{\mathrm{a}}$ & $9.17 \pm 0.63^{\mathrm{a}}$ & $42.42 \pm 4.92^{\mathrm{a}}$ & $30.29 \pm 1.37^{\mathrm{a}}$ & $76.35 \pm 5.92^{\mathrm{a}}$ \\
\hline
\end{tabular}

Mean \pm SEM, $n=3-4$.

a Significantly different from ascorbic acid (reference) $(t$-test; $p<0.05)$. 
Several authors $(10,11)$ have described a positive correlation between phenolic content and antioxidant activity using similar assay systems. However, we have not observed such type of correlation. This could be explained by the fact that factors other than total phenolics can play a major role in the antioxidant activity of these extracts. Boligon et al. (12) and Kiliçgün and Altiner (13) found no correlation between phenolic content and antioxidant activity measured by various methods, either.

All the extracts exhibited a significant inhibitory effect on $\mathrm{Fe}^{2+}$-induced TBARS production in brain homogenates $(p<0.05)$ and at $10 \mu \mathrm{g} \mathrm{mL}^{-1}$ a maximal inhibitory effect was attained for all the fractions (Fig. 2a). Similarly to what was observed with extracts obtained with organic solvents, cold and hot water extracts of T. catigua significantly inhibited $\mathrm{Fe}^{2+}$-induced TBARS production in brain homogenates in a concentration-dependent manner (Fig. 2b) $(p<0.05)$.

Free $\mathrm{Fe}^{2+}$ can induce neurotoxicity via stimulation of the Fenton reaction and its levels are increased in some degenerative diseases. T. catigua extracts inhibited $\mathrm{Fe}^{2+}$-induced lipid peroxidation in brain homogenates and this antioxidant effect can, at least partly, be associated with iron chelation. In fact, the chelating effects of some plant extracts could be attributed to the presence of flavonoids, which are well known to be chelator compounds. T. catigua extracts possess flavonoids, among which are quercetin and rutin (Fig. 3, Table I) that may form redox inactive complexes with $\mathrm{Fe}^{2+}$, rendering this pro-oxi-

Fig. 2. Effects of (a) crude extracts and (b) aqueous extracts from the stem bark of T. catigua on $\mathrm{Fe}^{2+}\left(10 \mu \mathrm{mol} \mathrm{L}{ }^{-1}\right)$-induced TBARS production in brain homogenates. The samples were incubated for $1 \mathrm{~h}$ with $\mathrm{Fe}^{2+}$ in the presence or absence of plant extracts (basal). Mean \pm SEM, $n=3-4$ independent experiments. Significant difference: a) $p<0.05$ vs. basal, b) $p<0.05$ vs. $\mathrm{Fe}^{2+}+$ ethanol (used as solvent), $p<0.05$ vs. $\mathrm{Fe}^{2+}$ alone.
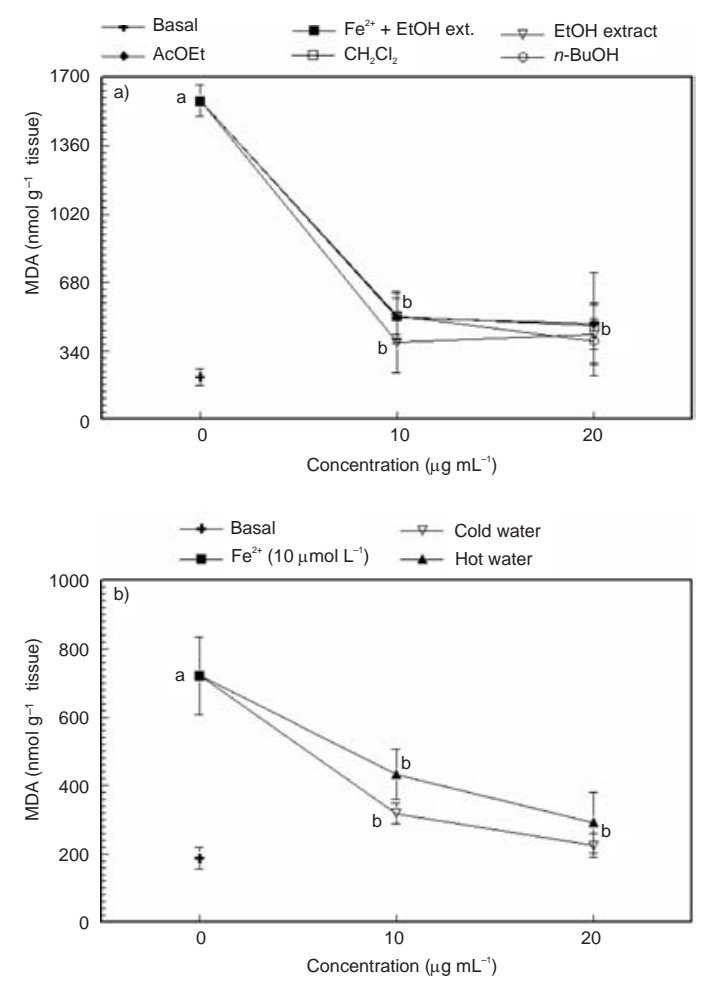

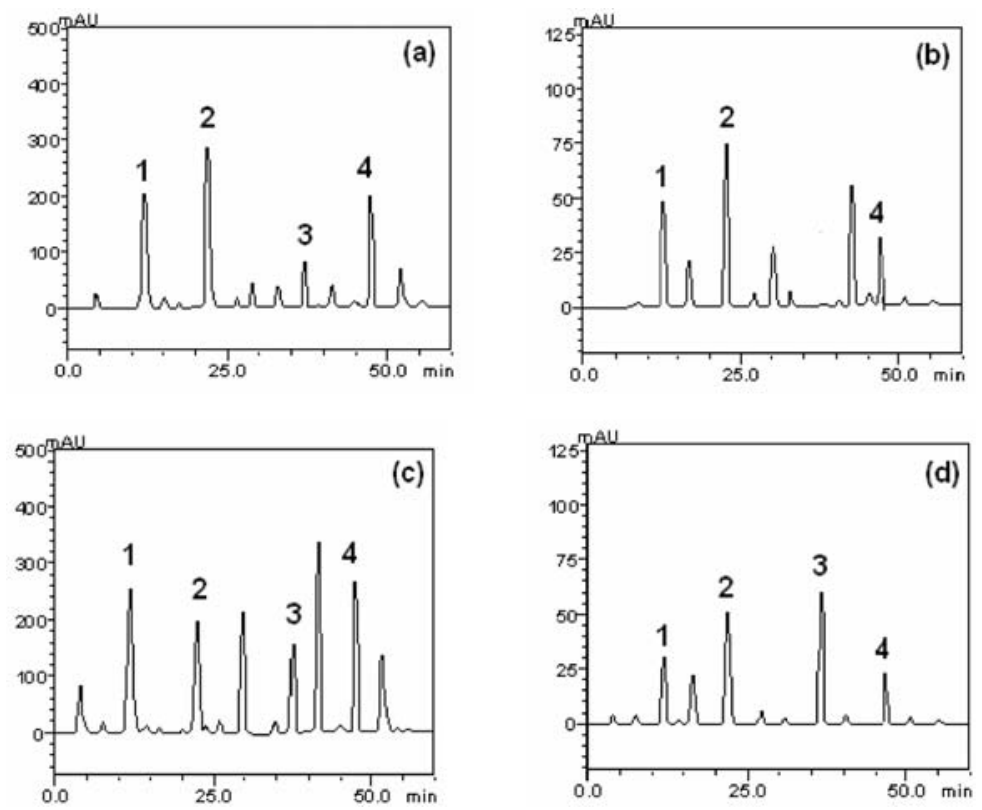

Fig. 3. High performance liquid chromatographic profile of phenolics and flavonoids in: a) ethanolic, b) dichloromethane, c) ethyl acetate, d) butanolic extract of T. catigua. Gallic acid (peak 1), chlorogenic acid (peak 2), rutin (peak 3) and quercetin (peak 4).

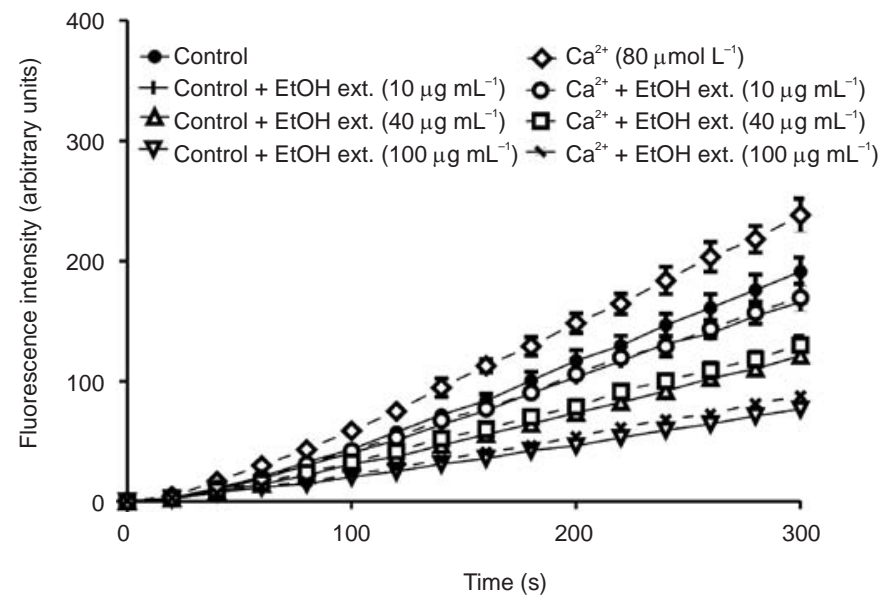

Fig. 4. Effect of calcium and ethanolic extract of T. catigua on rat liver mitochondrial DCFH oxidation. Mitochondria $\left(0.25 \mathrm{mg}\right.$ protein $\left.\mathrm{mL}^{-1}\right)$ were suspended in respiration buffer and mitochondrial ROS generation was determined by monitoring the fluorescence of $\mathrm{DFCH}$ oxidation (emission at $525 \mathrm{~nm}$ with excitation at $488 \mathrm{~nm}$. Mean \pm SEM, $n=4$ independent measurements. 
a)

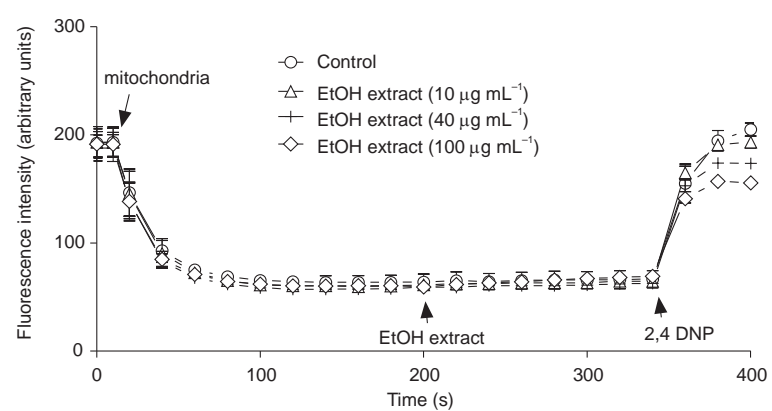

b)

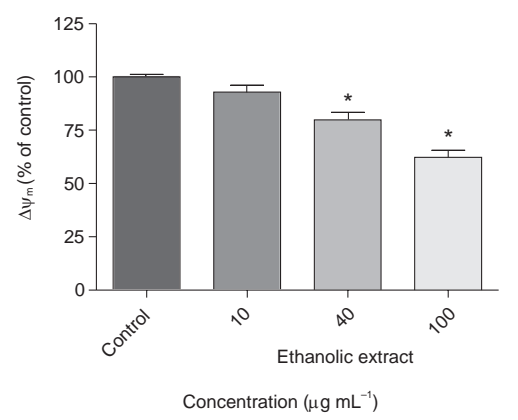

Fig. 5. Effect of ethanolic extract of T. catigua on mitochondrial membrane potential. Isolated rat liver mitochondria $\left(0.6 \mathrm{mg} \mathrm{mL}^{-1}\right)$ were incubated in standard medium and the $\Delta \psi_{\mathrm{m}}$ was monitored as described in experimental session. a) Effect of ethanolic extract $\left(10-100 \mu \mathrm{g} \mathrm{mL}^{-1}\right)$ on mitochondrial membrane potential; b) values of $\Delta \psi_{\mathrm{m}}$ after adding the mitochondrial uncoupler 2,4-dinitrophenol (2,4-DNP). The mitochondria $\left(0.6 \mathrm{mg} \mathrm{mL}^{-1}\right)$, ethanolic extract or 2,4-DNP were added where indicated by arrows. Experiments were performed three times using independent mitochondrial preparation. Mean \pm SEM, $n=3$. ${ }^{*}$ Significant difference $v$ s. control: $p<0.05$.

dant unavailable for Fenton reaction. Accordingly, quercetin and its glycoside form, rutin, effectively block $\mathrm{Fe}^{2+}$-induced TBARS production in brain homogenates (14).

Mitochondrial oxidation of DCFH was stimulated by $\mathrm{Ca}^{2+}\left(80 \mu \mathrm{mol} \mathrm{L}{ }^{-1}\right)$ and the ethanolic extract of $T$. catigua prevented ROS production stimulated by $\mathrm{Ca}^{2+}$ in a concentration-dependent fashion (Fig. 4). Substantial evidence in the literature has indicated that $\mathrm{Ca}^{2+}$ can increase mitochondrial oxidative stress (15). In line with this, $\mathrm{Ca}^{2+}$ increased the rate of DCFH oxidation compared to the control. Interestingly, the production of ROS induced by $\mathrm{Ca}^{2+}$ in the presence of ethanolic extract was not significantly different from those produced during basal conditions (control). This suggests that ROS production induced by $\mathrm{Ca}^{2+}$ was fully suppressed by the ethanolic extract, which is in accord with previous data from our laboratory indicating that quercetin, quercitrin and rutin protected brain mitochondria from $\mathrm{Ca}^{2+}$-induced oxidative stress (16).

Ethanolic extract of T. catigua at high concentrations $(40-100 \mu \mathrm{g} \mathrm{mL}-1$ ), produced a decrease in $\Delta \psi_{\mathrm{m}}(\sim 20 \%$ and $\sim 38 \%$ depolarization, respectively) compared to the control 
$(p<0.05)$ whereas no effect was observed at $10 \mu \mathrm{g} \mathrm{mL}-1$ (Figs. 5a,b). However, a partial decrease in $\Delta \psi_{\mathrm{m}}$ can be associated with cardioprotection, which may be related to a reduction in mitochondrial ROS production (17). Consequently, the in vitro decrease in mitochondrial ROS production by T. catigua can be related to the partial depolarization of mitochondria.

\section{CONCLUSIONS}

Crude extracts from the stem bark of T. catigua have in vitro antioxidant activity in different chemical and biological models, which can be, in part, attributed to flavonoids and phenolic compounds present in the plant extracts. Taken together, our results indicate that $T$. catigua has promising compounds to be tested not only as potential antioxidant drugs for the treatment of diseases resulting from oxidative stress, but also for the use in different fields such as pharmaceuticals and cosmetics.

Acknowledgements. - JPK would like to thank especially TWAS-CNPq for financial support. JPK is a beneficiary of the TWAS-CNPq postgraduate (doctoral) fellowship. Work was supported by CNPq, CAPES, FAPERGS, FAPERGS-PRONEX-CNPq, VITAE Fundation, Rede Brasileira de Neurociências (IBNET-FINEP), FINEP-CTINFRA and INCT for excitotoxicity and neuroprotection-CNPQ.

\section{REFERENCES}

1. S. Hasani-Ranjbar, B. Larijani and M. Abdollahi, A systematic review of the potential herbal sources of future drugs effective in oxidant-related diseases, Inflamm. Allergy Drug Targets 8 (2009) $2-10$.

2. C. H. Oliveira, M. E. A. Moraes, M. O. Moraes, F. A. F. Bezerra, E. Abib and G. De Nucci, Clinical toxicology study of an herbal medicinal extract of Paullinia cupana, Trichilia catigua, Ptychopetalum olacoides and Zingiber officinalis (Catuama) in healthy volunteers, Phytother. Res. 19 (2005) 54-57; DOI: 10.1002/ptr.1484.

3. M. G. Pizzolatti, A. F. Venson, A. S. Júnior, E. F. A. Smânia and R. Braz-Filho, Two epimeric flavalignans from Trichilia catigua (Meliaceae) with antimicrobial activity, Z. Naturforsch. C 57 (2002) 483-488.

4. W. Tang, H. Hioki, K. Harada, M. Kubo and Y. Fukuyama, Antioxidant phenylpropanoid-substituted epicatechins from Trichilia catigua, J. Nat. Prod. 70 (2007) 2010-2013; DOI: 10.1021/np0703895.

5. S. Venkatesh, M. Deecaraman, R. Kumar, M. B. Shamsi and R. Dada, Role of reactive oxygen species in the pathogenesis of mitochondrial DNA (mtDNA) mutation in male infertility, Indian J. Med. Res. 129 (2009) 127-137.

6. R. L. Puntel, D. H. Roos, D. Grotto, S. C. Garcia, C. W. Nogueira and J. B. Rocha, Antioxidant properties of Krebs cycle intermediates against malonate prooxidant activity in vitro: a comparative study using the colorimetric method and HPLC analysis to determine malondialdehyde in rat brain homogenates, Life Sci. 81 (2007) 51-62; DOI: 10.1016/j.lfs.2007.04.023.

7. A. H. Laghari, S. Memon, A. Nelofar, K. M. Khan and A. Yasmin, Determination of free phenolic acids and antioxidant activity of methanolic extracts obtained from fruits and leaves of Chenopodium album, Food. Chem. 126 (2011) 1850-1855; DOI: 10.1016/j.foodchem.2010.11.165. 
8. R. L. Puntel, D. H. Roos, V. Folmer, C. W. Nogueira, A. Galina, M. Aschner and J. B. T. Rocha, Mitochondrial dysfunction induced by different organochalchogens is mediated by thiol oxidation and is not dependent on the classical mitochondrial permeability transition pore opening, Toxicol. Sci. 117 (2010) 133-143; DOI: 10.1093/toxsci/kfq185.

9. O. H. Lowry, N. J. Rosebrough, A. L. Farr and R. J. Randall, Protein measurement with the Folin phenol reagent, J. Biol. Chem. 193 (1951) 265-275.

10. Y. S. Velioglu, G. Mazza, L. Gao and B. D. Oomah, Antioxidant activity and total phenolics in selected fruits, vegetables and grain products, J. Agric. Food Chem. 46 (1998) 4113-4117; DOI: 10.1021/jf9801973.

11. C. Nencini, A. Menchiari, G. G. Franchi and L. Micheli, In vitro antioxidant activity of some Italian Allium species, Plant Food Hum. Nutr. 66 (2011) 11-16; DOI: 10.1007/s11130-010-0204-2.

12. A. A. Boligon, P. R. Pereira, A. C. Feltrin, M. M. Machado, V. Janoyik, J. B. T. Rocha and M. L. Athayde, Antioxidant activities of flavonol derivatives from the leaves and stem bark of Scutia buxifolia Reiss, Biores. Technol. 100 (2009) 6592-6598; DOI: 10.1016/j.biortech.2009.03.091.

13. H. Kiliçgün and D. Altiner, Correlation between antioxidant effect mechanisms and polyphenol content of Rosa canina, Pharmacogn. Mag. 23 (2010) 238-241; DOI: 10.4103/0973-1296.66943.

14. P. A. Omololu, J. B. T. Rocha and I. J. Kade, Attachment of rhamnosyl glucoside on quercetin confers potent iron-chelating ability on its antioxidant properties, Exp. Toxicol. Pathol. 63 (2011) 249-255; DOI: 10.1016/j.etp.2010.01.002.

15. M. J. Hansson, R. Månsson, S. Morota, H. Uchino, T. Kallur, T. Sumi, N. Ishii, M. Shimazu, M. F. Keep, A. Jegorov and E. Elmér, Calcium-induced generation of reactive oxygen species in brain mitochondria is mediated by permeability transition, Free Radical Biol. Med. 45 (2008) 284-294; DOI: 10.1016/j.freeradbiomed.2008.04.021.

16. C. Wagner, A. P. Vargas, D. H. Roos, A. F. Morel, M. Farina, C. W. Nogueira, M. Aschner and J. B. Rocha, Comparative study of quercetin and its two glycoside derivatives quercitrin and rutin against methylmercury (MeHg)-induced ROS production in rat brain slices, Arch. Toxicol. 84 (2010) 89-97; DOI: $10.1007 /$ s00204-009-0482-3.

17. F. Sedlic, A. Sepac, D. Pravdic, A. K. S. Camara, M. Bienengreber, A. K. Brzezinska, T. Wakatsuki and Z. J. Bosnjak, Mitochondrial depolarization underlies delay in permeability transition by preconditioning with isoflurane: roles of ROS and $\mathrm{Ca}^{2+}$, Am. J. Physiol. Cell Physiol. 299 (2010) C506-C515; DOI: 10.1152/ajpcell.00006.2010.

\title{
$S A \check{Z} E T A K$
}

\section{In vitro antioksidativni učinak kore stabljike Trichilia catigua Adr. Juss}

\author{
JEAN PAUL KAMDEM, SÍLVIO TERRA STEFANELLO, ALINE AUGUSTI BOLIGON, \\ CAROLINE WAGNER, IGE JOSEPH KADE, ROMAIANA PICADA PEREIRA, ALESSANDRO DE SOUZA PRESTE, \\ DANIEL HENRIQUE ROOS, EMILY PANSERA WACZUK, ANDRE STORTI APPEL, MARGARETH LINDE ATHAYDE, \\ DIOGO ONOFRE SOUZA I JOÃO BATISTA TEIXEIRA ROCHA
}

U radu je opisano ispitivanje antioksidativnog učinka etanolnog ekstrakta i pojedinih frakcija kore stabljike T. catigua. $I C_{50}$ (za DPPH test) varirao je između 9,17 $\pm 0,63 \mathrm{i}$ $76,42 \pm 5,87 \mu \mathrm{g} \mathrm{mL}^{-1}$, a ukupni sadržaj fenola od 345,63 $\pm 41,08$ i $601,27 \pm 42,59 \mu \mathrm{g}$ GAE po gramu suhog ekstrakta. Etanolni ekstrakt i frakcije značajno su reducirale $\mathrm{Fe}^{2+}$-induciranu lipidnu peroksidaciju. Nadalje, reducirana je oksidacija diklorfluoresceina inducirana ionima kalcija u mitohondrijima, a redukcija je ovisila o dozi etanolnog ekstrakta. 
Etanolni ekstrakt smanjio je mitohondrijsku $\Delta \psi_{\mathrm{m}}$ samo pri visokim koncentracijama (40 \pm $100 \mu \mathrm{g} \mathrm{mL}^{-1}$ ), što ukazuje da se toksičnost ne preklapa s antioksidativnim učinkom. Rezultati pokazuju da u farmakološko djelovanje T. catigua treba uključiti i antioksidativni učinak.

Ključne riječi: Trichilia catigua (Meliaceae), antioksidans, flavonoidi, fenoli, reaktivne kisikove specije, oksidativni stres

Departamento de Química, Programa de Pós-Graduação em Bioquímica Toxicológica, Universidade Federal de Santa Maria, Santa Maria, RS 97105-900, Brazil

Departamento de Farmácia Industrial, Programa de Pós-Graduação em Ciências Farmacêuticas Universidade Federal de Santa Maria, Santa Maria, RS 97105-900, Brazil

Universidade Federal do Pampa, Campus Caçapava do Sul, Caçapava do Sul, RS CEP 96570-000, Brazil

Department of Biochemistry, Federal University of Technology, PMB 704 Akure, Ondo State, Nigeria

Departamento de Bioquímica, Instituto de Ciências Básicas da Saúde, Universidade Federal do Rio Grande do Sul, Porto Alegre, RS, Brazil 